\title{
THE THERAPEUTIC EFFECTS OF SALICYLAMIDE UPON NEURALGIA AND ARTHRODYNIA OF LEPROUS PATIENTS
}

\author{
OEI UMEKI \\ National Leprosarium Kikuchi-Keifuen \\ IBepartment of Merlicine, Faculty of Medicine, Kumamoto University.
}

36 leprous patients with neuralgia and arthrodynia were treated with orally administered Salicylamide.

The results are follow's:

1) 20 of 36 patients are improved by this treatment.

2) The administration of $3 \mathrm{gm}$. daily is not enough. The required dosis is 6 to $8 \mathrm{gm}$, daily.

3) In 16 patients $(44.4 \%)$ there are side-effects of this drug, mostly consisting of symptoms of stomach.

\section{癩患者に於ける神経痛並に関節痛のサリチ ルアミド療法}

国立瘵荃所菊池萝楓園（園長 宫崎松記）

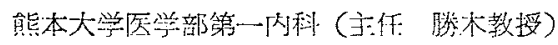

㮠木旺喿

(昭利 28 行4.月16日受融)

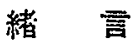

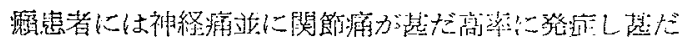

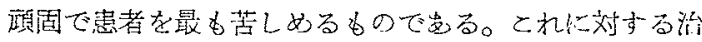

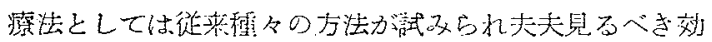

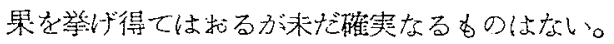

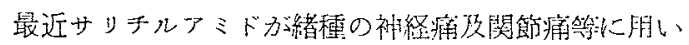

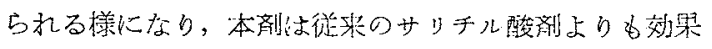
ガ大で且副作朋方少ないと云われている。とれについて

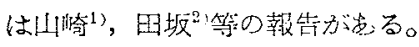

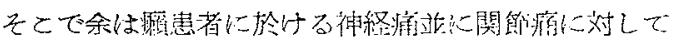

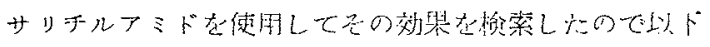
赫毕する。

\section{症例及使用法}

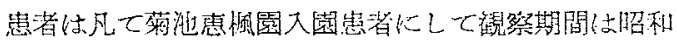

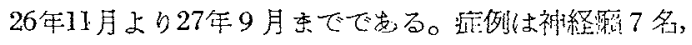

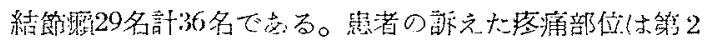

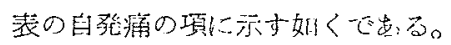

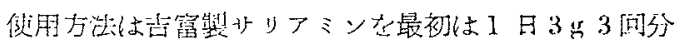

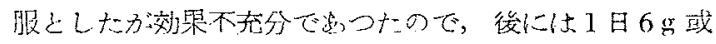

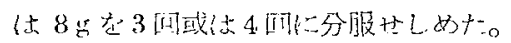

\section{成 績}

A) 踑痛効果

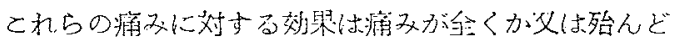

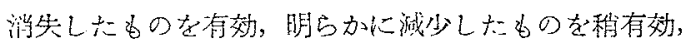

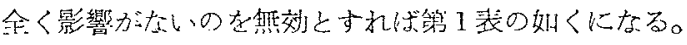

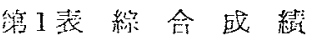

\begin{tabular}{|c|c|c|c|}
\hline 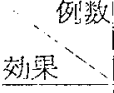 & 神経浯 7 名 & 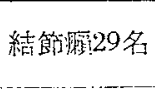 & 棓 36 名 \\
\hline 有 效 & $5(71.4,6)$ & $12(41.4 \%)$ & $17(47.2,0)$ \\
\hline 稍有效 & $1(14.3 \% 6)$ & $2(6.9 \%)$ & $3(8.3 \%)$ \\
\hline 無 效 & $1(14.3 \% 6)$ & $13(44.8,6)$ & $14 .(38.996)$ \\
\hline 不 明 & 0 & $2(6.9 \%)$ & $2(5.6 \%)$ \\
\hline
\end{tabular}




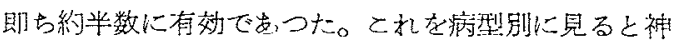

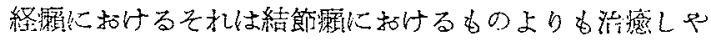

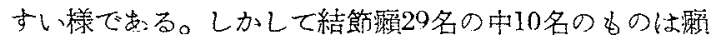
性結節性紅斑以合併したもので老つて，てれら10名中効 果の多つたの心僅か心 1 名に過ぎず俍は然效 7 名, 不明 名ですつだ。

次に䀧患者に於け吕神経痛は屡々多発性に来り然女関節 痛を它併ならものが多いが，これ等老部位別に見ると第

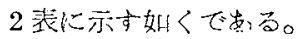

第 2 瑟 痛部位と諸効果

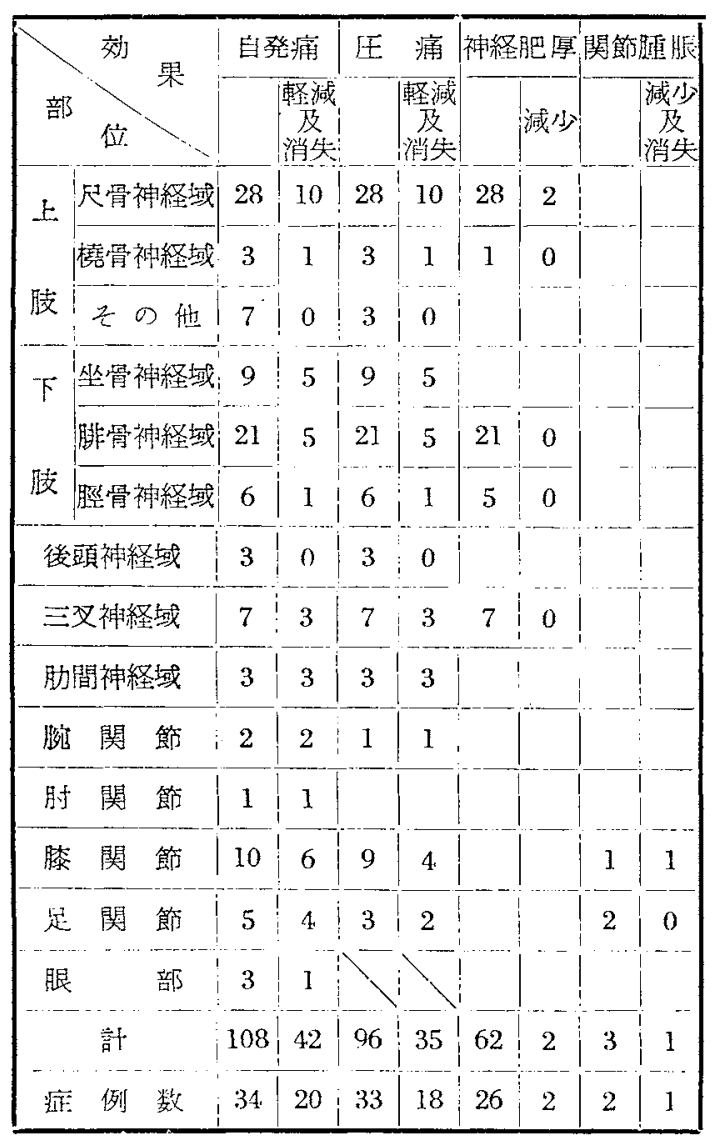

詮：効果不明の 2 名杂除く

先つ自永痛心関しては助届神経痛の3 例は全例有效で

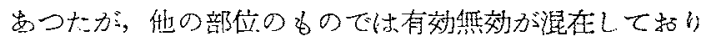

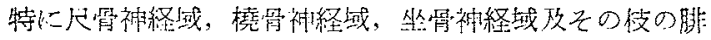

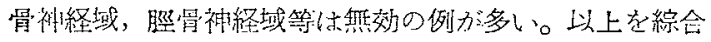

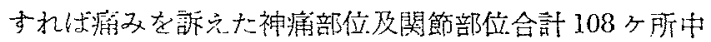

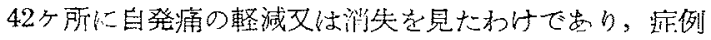
で云えば有效，稍有效が20名で多つた。

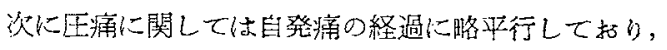

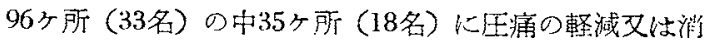
失在諰め\%。

B）その他の効果

神経肥厚は㿋の特街でるるが，自登痛及汪痛の存する

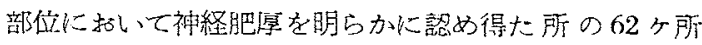
(26名)の中でその肥厚の堿退を証明し得たのは2ヶ所 (2名)に週志加つた。

又関節の腫胀を認めたのは18ヶ所 (9名)の中 3 前 (2名)で出り，その減少消失を竐明し得たのは1万市

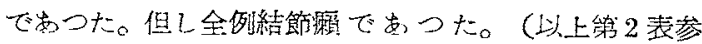
经)

\section{C) 传用㻎と效果}

使用量と效果との関係を是るに，第 3 義に示す如く始 めの5名に対しては1日量 $3 \mathrm{~g} 3$ 回分服としたがこれ らの中 1 名にのみ有效で女つて 3 名は6 gに堌量して始 めて有效上なつた。

第3表 投与法別に見た効果

\begin{tabular}{|c|c|c|c|c|}
\hline 投与法 & 有 效 & 稍有效 & 無 効 & 不 明 \\
\hline $3 \mathrm{~g}: 5$ 名 & 1 & 0 & (3) & I \\
\hline $6 \mathrm{~g}: 5$ 名 & 3 & 0 & 2 & 0 \\
\hline $8 g: 26$ 名 & 10 & 3 & 12 & 1. \\
\hline
\end{tabular}

依つて次の5名に対しては1日量 $6 \mathrm{~g} 3$ 回分服とした が有效は3名ですつた。それで媵の26名に対しては1 日最 $8 \mathrm{~g} 4$ 回分服とした。その結果は有効 10 名, 稍有効 3 名で亚つた。即ち $3 \mathrm{~g}$ で明らかに不充分で告るが $6 \mathrm{~g}$ と $8 \mathrm{~g}$ との間には著明な差は認められなかつた。次 に投与全量は有效例で显小最 $24 \mathrm{~g}$ ，最大最 $153 \mathrm{~g}$ ，無 效例厄は最小量 $32 \mathrm{~g}$ ，最大量 $104 \mathrm{~g}$ でかり，100g 以上投 与したのは有効例中 4 名，無效例中了名で他の大部分が $100 \mathrm{~g}$ 以下の搑与例であつた。

\section{D) 再. 発}

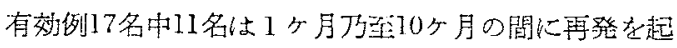
してるないが，䛧の6名は夫夫再発した。再登例中 4名

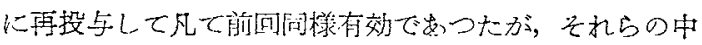
特に電症ですつた 2 名はその後も再登者繰返し特に1名

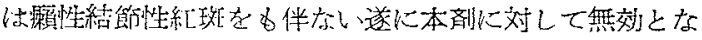

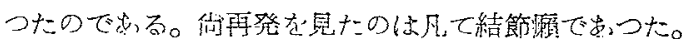


E) 副作用

副作用発現率は36名中16名則ち44.4\%で步つてその内 容は第表に示す通りでるる。

營 4 表 副 作 用

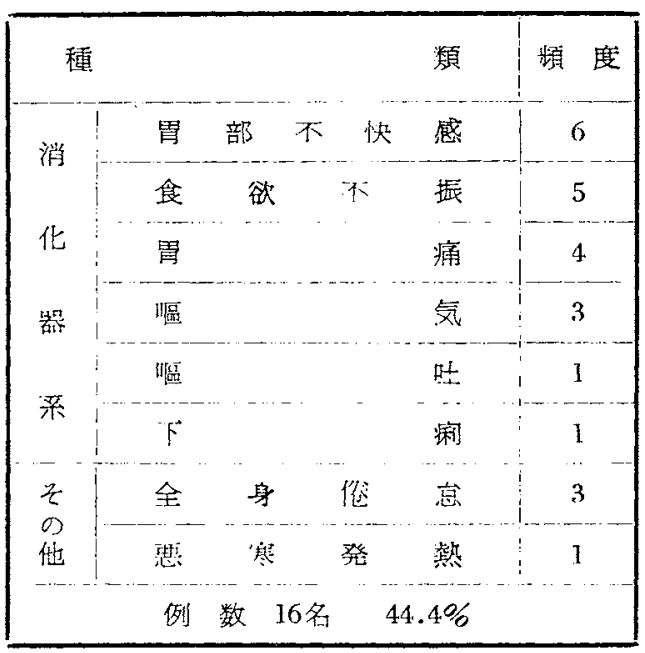

即ら副作用の大部分は舅媁棏ですつた。しかしてとれ 等の胃障碍を呈した11名中 5 名は本削投与前仁既心胃淀 状を軽度乍ら有していたものが本剂投与により更に堌想 したものでまる。そしててれらの胃障碍は制酸戍，鎮吐

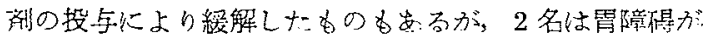
些だしくてサリチルアミドの服菂中止を余儀なくされ，

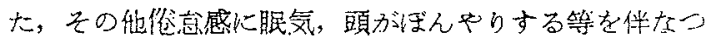

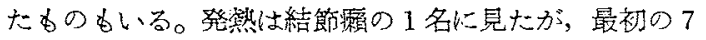

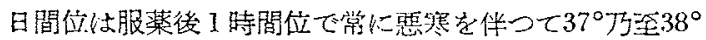

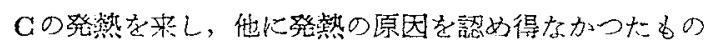
である。

\section{総括並に考按}

サッチルアミドを顆密者に使用した報告を末だ見ない

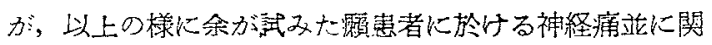
節痛に対するサッチルアミドの效果は約半数に有效で告 つた。即ち本剂も亦促来種々試みられた治療法に比べて より以上の効果を挙げることは出来なかつた。この成績

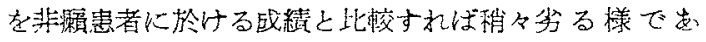
る。即ち多くの報告に見られる樣何何孔著効若くは相

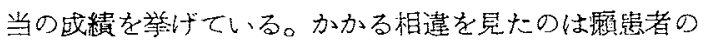
神経痛はすべて看候性でめり，その神経は特有の䠝性の 器質的変化を来して如り特に急性堌恶期には更にその病

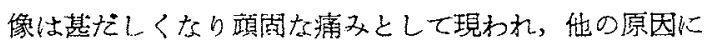
よるるのとは比すべくるなく項固でまるからであろら。

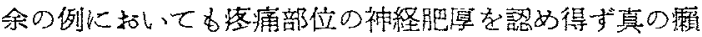
性神経痛と断定し得なかつ大肋問神経痛例儿は全例有効 であつたのに反し，神経肥厚を認如得大他の部位の神経 痛には無効の例が多かつた。

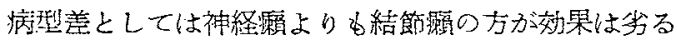

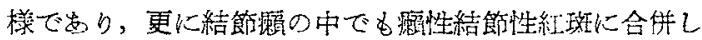
たものは特に碩固であることは日頃経験する所である が，余の例の中10名がそれでその大部分が無効であつた ことは此の間の事情を物語るすのでめろら。

使用量炕関しては一般に1日3gkては不充分で $6 \mathrm{~g}$ 或は $8 \mathrm{~g} を 3$ 回或は 4 回以上に径服させるが良いと云わ

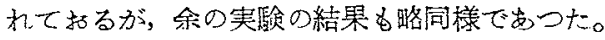

副作用は非䎦患者の成績に比べてその発現度が大きい 様でま:つて，殊に胃㜔碍が相当の数に上つているが，元

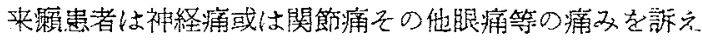
る者が多く且萋々再発して，種々のサりチ儿酸㓮を内服

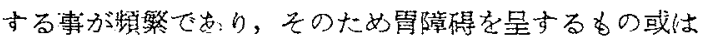

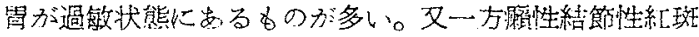
は同時に胃障㥂を伴ならととが多いのである。これらの

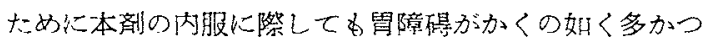
犬ものと思考される。

しかしてサリチル酸剧の作用機転として、ニーチン゙ン 様作用，或はAＣＴH作用があるとの報告があり ${ }^{3)}$ ， 及

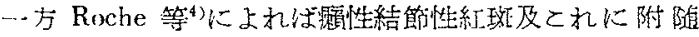
する各種の疼痛に対してACTHは著效を抢さめたとの

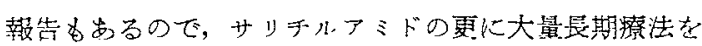
帄能ならしぬたならばより以上の効果吕期待される。

\section{結語}

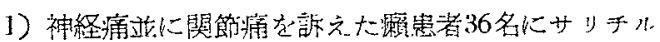
アミドを投与してその半数に効果を認め大。

2）使用量は1日 3 grでは不充分です。 $6 \mathrm{~g}$ 万至 $8 \mathrm{~g}$ むる。

3）副作用は44\%に認好られ胃障碍が大部分であつ た。

（終江御指導，御校閲を賜つ大勝木教授，椬䗁園骎， 志賀医務課長比梁謝す。)

\section{交献}

1) 山崎睛一郎：福阙医学雑誌，43（5）, 昭 27

2）田坂 定孝：最新医学，7（1），昭27

8) Pelloja : Lancet, 1 ( 5 ) , 1952

4) Roche et al.: Int. J. Leprosy, 19 (2) , 1951 